\title{
112 dager om våren
}

Jeg ankommer om morgenen, med en sekk og en bag. Jeg puster dypt et par ganger før jeg ringer på døren. Nå er det ingen vei tilbake. Hvordan skal de neste ukene bli?

Min første dag på institusjon. Første dag som innlagt for å kjempe min egen krig, sammen med 17 menn og fem damer. Men likevel så alene. Inni meg er det fullt kaos, og jeg vet ikke lenger hvor jeg hører til eller hvem jeg hører til.

Jeg blir møtt av spørsmål om det er første gangen min her, om jeg er her for alkohol eller piller, om jeg kommer hjemmefra eller fra avrusning. Jeg må plasseres. Kategoriene er helt annerledes enn andre steder jeg har vært, alle er kun på fornavn og de færreste vet $\mathrm{i}$ utgangspunktet hva de andre driver med. Det er opp til den enkelte hvor mye man vil fortelle. Jeg er kategorisert med alkohol, kommer hjemmefra, ikke vært her før, kvinne, i 30-årsalderen, og mor.

\section{Jeg passer ikke inn}

Her er jeg ikke akademiker eller intellektuell. Her er jeg en person med problemer. En som trenger hjelp for å få orden på livet. Fagpersonen og omsorgspersonen er lagt bort og ingen forventer noe annet enn at jeg skal gjøre de få pliktene vi har her, kjøkkentjeneste og litt vasking. Alt jeg ellers gjør er kun for meg selv og for min egen del. Det er bare meg det går utover hvis jeg ikke presterer. Ute i verden er det helt andre krav. Vi skal mestre og lykkes - på jobb og som mor. Men hvem kan klare å leve opp til alle kravene og forventningene? Jaget etter å lykkes, etter å være i posisjon, koster ikke bare for den enkelte, men for samfunnet. Noen tyr til rusen for å overleve, paradoksalt nok.

Ikke å være i jobb er vanskelig. Mange av mine medinnlagte er sosialklienter eller på trygd, og det er jo faktisk jeg også, selv om jeg ikke liker å tenke på det. Når rusen i tillegg har fått en solid plass i livet, blir man ofte møtt med lite respekt. Man kommer inn i en ond sirkel det ikke er lett å bryte. Jeg tilhører en utsatt og stigmatisert gruppe, som jeg samtidig har et stort behov for å distansere meg fra.

Alle er vennlige - både innlagte og ansatte. De vet at de første dagene er tøffe, og jeg blir tatt fort inn i varmen. Røykerommet er et godt sted. Det er der vi blir kjent. Etter noen dager får jeg lov til å gå i butikken. Det føles som om det står stemplet i pannen at jeg kommer fra den røde murbygningen oppe i veien. Jeg tror alle jeg møter på veien kan se at jeg er en av dem. En av alkoholikerne. Men jeg er jo ikke det? Bak i hodet hører jeg stemmen som sier at jeg er annerledes, at jeg egentlig ikke hører til. Kanskje er jeg faktisk ikke god nok alkoholiker? Det er en fin tanke, for da skulle jeg jo egentlig ikke vært her, og jeg er slett ikke som de andre. Samtidig så vet jeg at flere av de andre tviler på det samme.

\section{«Jeg tilhører en utsatt og stigmatisert gruppe, som jeg samtidig har et stort behov for à distansere meg fra»}

Er vi verdige nok til å være her? Til å oppta en behandlingsplass til fordel for noen andre? Det er mange som venter i kø, som sikkert har det mye verre og som trenger plassen mye mer. Hun jeg overtok senga etter hadde sprukket og blitt kastet ut helgen før jeg kom. Hun døde av en overdose to dager etter at jeg kom inn. Dette er alvor.

Etter hvert tar jeg innover meg at jeg trenger å være her, selv om jeg stritter imot. Er jeg egentlig så annerledes? Bildet jeg hadde på forhånd, stemmer jo ikke. Det er slett ikke mange gamle slitne gubber, som jeg trodde. Jeg må nok skrive historien min på nytt og ikke tro at jeg er annerledes eller bedre enn de andre. For å være best mulig mottakelig for behandling er det helt nødvendig å tro på at jeg har et stort nok problem med alkohol, selv om det sitter langt inne å erkjenne det.

\section{Alkohol overalt}

Paller med øl er det første jeg ser i butikken. Jeg blir tørr i munnen og kjenner at musklene i halsen strammer seg. En følelse jeg kjenner så altfor godt tar plass. Alkoholsuget river i kroppen og lager tunnel i hodet. Det eneste som blir viktig er å drikke. Men nå skal jeg ikke det! Heldigvis er jeg ikke alene, så jeg henger meg på henne jeg er ute sammen med. Vi finner godteriet vi skal ha, brus og røyk, betaler og går raskt tilbake til tryggheten. Jeg puster lettet ut når vi er innenfor døren, men er også skremt over meg selv. Hvordan skal dette gå? Jeg må jo kunne gå i butikken uten å risikere å sprekke. Pallene med øl, som alltid er plassert slik at kundene må gå forbi, blir ekstra synlige når de er forbudte. Forbudet gjør det ekstremt synlig at alkohol har en stor plass i samfunnet og livet. Det foregår ikke en eneste fest uten at alkohol serveres og drikkes. Vinlotterier og lønningspils på arbeidsplasser er vanlig. For dem som ikke har et problem med alkohol, er det selvfølgelig ikke noen utfordring, men for alle dem som har et problem, er det vanskelig. Og det gjelder flere og flere.

De aller fleste krever at alkohol skal være en naturlig del av livet. "Vi må drikke mer kontinentalt,» sier Oslos middelklasse. Og de drikker mer. Nå har jeg ikke havnet her fordi jeg har forsøkt, og feilet i, å drikke kontinentalt. At mitt alkoholbruk har eskalert og gått over alle vidder, skyldes en rekke andre grunner. Men samfunnets holdninger til alkohol påvirker folks drikkemønster og gir større muligheter for stort alkoholkonsum uten at noen reagerer. Det gjør det enklere å rettferdiggjøre egen stordrikking. Konsumet av alkohol har økt mye de siste tiårene, særlig blant kvinner. Forskere sier at det er en sammenheng mellom tilgjengelighet, pris og forbruk. Vi kan forvente at det blir flere som utvikler et problematisk drikkemønster som de trenger hjelp til å komme ut av - i tide.

\section{Ikke for kvinner}

$\AA$ være kvinne i en behandlingssituasjon som tradisjonelt har vært for menn, er vanskelig. Selv denne klinikken som bl.a. profilerer seg på kompetanse om kvinner, er preget av mangelfull kunnskap og innsikt i det spesielle med å være kvinne med rusproblem. Veldig mye av behandlingen er tilrettelagt for menn, for han som har drukket i flere tiår, er gjenganger i behandlingssystemet og som snart vil miste jobb, hjem og familie - om han ikke allerede har gjort det. Det er han vi lærer om i undervisningen, ikke meg. Jeg føler meg utenfor og kjenner meg ikke igjen i det hele tatt.

At alkoholbehandlingsarenaen er dominert av menn, både i antall og i oppmerk- 
somhet, gjør meg usikker på om dette stedet er for meg. Heldigvis er min behandler, en flink psykolog, mer oppdatert enn mange av de andre på huset. Han skjønner at å ha et alkoholproblem er noe annet for meg enn for en mann på 50. Jeg er ung mor, noe som betyr helt andre utfordringer og krever et annet fokus enn for den mannen klinikken er designet for. Mannsdominansen i behandlingsapparatet holder faktisk kvinner unna å søke hjelp. Det er et problem både for kvinnene som ønsker å søke og for kvinnene som er i behandling allerede. Hadde det kanskje vært bedre med kjønnsdelt behandling? Noen mener det, og noen praktiserer det. Jeg vet ikke. Tanken bak er ikke bare at det er andre forhold som spiller inn for kvinner, men også det faktum at mange kvinner med rusproblem har et problematisk forhold til menn. Mange har vært i destruktive forhold og mange har også vært utsatt for overgrep fra menn både før og under ruskarrieren. Men det kan kanskje være sunt å bli kjent med og forholde seg til menn i en i utgangspunktet ufarlig setting? Samtidig er mange av dem som er i behandling preget av grenseløshet, noe som raskt kan bli problematisk. Vi blir rådet til ikke å inngå kjærlighetsforhold mens vi er innlagt, for det kan forstyrre fokuset $\mathrm{i}$ behandlingen. Det er lettere sagt enn gjort.

Når kvinner inntar tradisjonelle mannsarenaer med mye alkohol og det samtidig er sterkere fordommer, stigma og skam knyttet til kvinnelige storbrukere av alkohol enn til menn i samme situasjon, da blir kvinnen en dobbelttaper. Hva skjer når heller ikke behandlingsapparatet er rede til å se og behandle kvinnene som oppsøker dem? Hvis de oppsøker det.

\section{Hvordan skal jeg klare det?}

- Hvor mange ganger har du vært her, du da? spør jeg en av dem som ikke er så mye eldre enn meg selv, men som virker veldig

\section{«A være kvinne i en behandlingssituasjon som tradisjonelt har vært for menn, er vanskelig»}

husvarm. - Dette er tredje gangen. Sist gang var for to år siden. De fleste må gå flere runder, vet du. Å nei, tenker jeg, det har ikke jeg tenkt! Kjenner at jeg mister motet bare av tanken. Noen uker her må da være nok? På den annen side, hvorfor skulle jeg klare det når nesten ingen andre gjør det? Tanken får det til å suse i hodet mitt. Hele verden gynger, ingenting er stødig og stabilt. - Problemet er at alle der ute tror du er frisk når du kommer ut herfra, hører jeg han si langt borte.

Jeg forstår ikke, og vil ikke forstå, at det prosjektet jeg nå er i gang med er så vanskelig. Jeg skjønner ikke at noen har vært her mange ganger. Jeg er utålmodig og vil ha det bedre. For å få det bedre må jeg slutte å drikke. Da gjør jeg det, det er jo derfor jeg er her! Stadig vekk er det noen rundt meg som sprekker og må ut. Jeg spør meg stadig om hva de driver med. Vil de ikke slutte å drikke? Hvorfor er de her da?

Etter hvert som tiden går øker tvilen på om jeg kan klare dette og om jeg egentlig vil. Hvorfor skal jeg klare det når ingen andre gjør det? Hvorfor skal jeg gidde å streve så mye når det likevel ikke går? Når alt kommer til alt har jeg ikke noe valg. Jeg har to barn der hjemme som trenger en frisk mamma. Den ene dagen er jeg dønn motivert og målrettet, den neste har jeg bare lyst til å skrive meg ut og drikke meg full. Jeg kan ikke fatte hvordan jeg skal klare å holde meg edru på utsiden. Hvordan skal jeg klare å takle nedturer uten å ty til alkohol? Hører jeg til her likevel?

\section{Anonym}

Forfatteren ønsker å være anonym, men vedkommendes identitet er kjent for redaksjonen.

Mottatt 1.10. 2012, første revisjon innsendt 24.10. 2012, godkjent 1.11. 2012. Medisinsk redaktør Erlend Hem. 